\title{
Development, characterization and stability of microemulsionated formulations of bacaba, Oenocarpus bacaba oil
}

\author{
Maycon de Paula Ribeiro TORRES ${ }^{1}$, Rhuan Vínicius de Freitas ESPRENDOR², Solange Maria BONALDO ${ }^{3}$, \\ Elton Brito RIBEIRO², Dênia Mendes de Sousa VALLADÁO ${ }^{1 *}$ (1) \\ Universidade Federal de Mato Grosso, Campus Sinop, Instituto de Ciências da Saúde, Programa de Pós-Graduação em Ciências Ambientais, Av. Alexandre \\ Ferronato, 1200, CEP 78.557-267, Sinop, Mato Grosso, Brasil \\ 2 Universidade Federal de Mato Grosso, Campus Sinop, Instituto de Ciências da Saúde, Av. Alexandre Ferronato, 1200, CEP 78.557-267, Sinop, Mato Grosso, Brasil \\ Universidade Federal de Mato Grosso, Campus Sinop, Instituto de Ciências Agrárias e Ambientais, Programa de Pós-Graduação em Ciências Ambientais, Av. \\ Alexandre Ferronato, 1200, CEP 78.557-267, Sinop, Mato Grosso, Brasil \\ * Corresponding author: deniavalladao@gmail.com; (I) https://orcid.org/0000-0002-2643-1963 \\ (1) https://orcid.org/0000-0002-2240-2700
}

\begin{abstract}
Advances in nanotechnology, combined with the use of natural products, represent a promissing research field. Brazil is a country of a rich biodiversity, especially in the Amazon forest. Fruits commonly used by local communities, such as bacaba (Oenocarpus bacaba), are potentially important for prospection of industrial applications of natural products. In nanotechnology, microemulsions stand out for providing a modified release to conveyed substances. This work aimed to develop microemulsionated formulations of bacaba oil, characterize them and evaluate their stability. We determined the HLB (hydrophile-lipophilic balance) of bacaba oil for formulation development. Six formulations were selected from pseudoternary diagrams, which indicated the proportions of surfactants, aqueous phase and bacaba oil. The viability of these formulations was evaluated through stability tests. We provided the rheological characterization of the formulations, evaluated their potential antioxidant activity through the DPPH (2,2-diphenyl-1-picrylhydrazyl) radical scavenging method, and determined the hydrodynamic diameter of the droplets. The microemulsions were stable throughout the test period. Droplet diameter was below $200 \mathrm{~nm}$, and the microemulsions were characterized as newtonian fluids, presenting an increase in antioxidant activity when compared with the diluted oil. Our results confirm the potential of bacaba oil in microemulsionated formulation as a suitable carrier for active compounds.
\end{abstract}

KEYWORDS: microemulsion, Amazon, native fruit, nanotechnology, carriers

\section{Desenvolvimento, caracterização e estabilidade de formulações microemulsionadas de óleo de bacaba, Oenocarpus bacaba}

\section{RESUMO}

Os avanços no âmbito da nanotecnologia, aliados ao uso de produtos naturais, representam uma área promissora de pesquisa. O Brasil é um país de rica biodiversidade, especialmente na floresta amazônica. Frutos utilizados comumente nas comunidades locais, como a bacaba (Oenocarpus bacaba), são potencialmente interessantes para prospecção de aplicação industrial de produtos naturais. Na área da nanotecnologia, as microemulsôes se destacam por prover uma liberação modificada das substâncias veiculadas. Este trabalho teve como objetivo desenvolver formulaçóes microemulsionadas de óleo da bacaba, caracterizá-las e avaliar sua estabilidade. Determinamos o EHL (equilíbrio hidrófilo-lipófilo) do óleo da bacaba para o desenvolvimento das formulaçóes. A partir de diagramas pseudoternários, que indicaram as proporçóes de tensoativos da fase aquosa e do óleo de bacaba, foram selecionadas seis formulaçóes. A viabilidade dessas formulaçóes foi analisada por meio de testes de estabilidade. As formulaçóes passaram por caracterização reológica, avaliação do potencial de atividade antioxidante através da capacidade de redução do radical DPPH (2,2-difenil-1-picrilhidrazil), e determinação do diâmetro hidrodinâmico de suas gotículas. As microemulsóes mostraram-se estáveis durante o período de teste e apresentaram diâmetro de gotículas abaixo de $200 \mathrm{~nm}$, foram caracterizadas como fluídos newtonianos e apresentaram um aumento da atividade antioxidante quando comparadas com o óleo diluído. Nossos resultados indicam o potencial do óleo de bacaba em formulação microemulsionada para veiculação de diversos princípios ativos.

PALAVRAS-CHAVE: microemulsão, Amazônia, fruto nativo, nanotecnologia, carreadores

CITE AS: Torres, M. de P.R.; Esprendor, R.V. de F.; Bonaldo, S.M.; Ribeiro, E.B.; Valladão, D.M. de S. 2019. Development, characterization and stability of microemulsionated formulations of bacaba, Oenocarpus bacaba oil. Acta Amazonica 49: 246-255. 


\section{INTRODUCTION}

The Amazon rainforest holds about one third of the world's biological diversity (Albagli 2001). The use of this biodiversity in new technologies constitutes a great tool of scientific advancement and development of the industry in Brazil (Albagli 2001; Funari and Ferro 2005). Bacaba (Oenocarpus bacaba Mart.) is an Amazonian palm tree with a fruit that produces oil traditionally used in cooking. The fruit has great economic and nutritional potential, as its oil is rich in unsaturated fatty acids, mainly oleic and palmitic, and phenolic compounds (Balick 1986; Queiroz and Bianco, 2009; Finco et al. 2012; Pereira et al. 2013; Santos et al. 2017). Traditionally, the oil is extracted by boiling the fruit pulp (Cymerys 2005). However, the heat might lead thermosensitive substances to degradation, which calls for other methods that do not use high temperatures in the oil extraction process (Roy et al. 2006; Pinto et al. 2018). Studies concerning the biochemical activity of bacaba oil are scarce, but it has already been shown to have antioxidant and cardioprotective potential (Pinto et al. 2018).

Nanotechnology is a subject of research in several industries, due to the need of new carriers for active compounds, to convey natural substances that are difficult to incorporate in traditional forms, or to enhance productivity in agriculture (Bonifácio et al. 2014; Dasgupta et al. 2015). Nanostructured formulations can increase the selectivity and effectiveness of active compounds, as their delivery structures can surpass biological barriers that traditional formulations do not. They also convey protection against degradation, and reduce side effects by controlling the release of several substances, including plant extracts, which allows the association of two market trends, such as natural products and nanotechnology (Oliveira et al. 2004; Bonifácio et al. 2014; Katz et al. 2015; Costa and Santos 2017). Microemulsions present some advantages when compared to other nanostructured formulations (Bonifácio et al. 2014), since they are thermodynamically stable, isotropic and transparent systems of two immiscible liquids (usually water and oil), dispersed into each other in the form of nanometric droplets, stabilized by a interfacial surfactant/cosurfactant film, obtained without the need of energy addition (Lawrence and Rees 2012; Fanun 2012; Callender et al. 2017). These characteristics make microemulsions cheaper, easier and quicker to develop.

Thus, the aim of this work was to develop microemulsionated formulations with bacaba oil, to characterize them and to evaluate their stability in order to determine their potential capacity as carriers for the delivery of active compounds.

\section{MATERIAL AND METHODS}

\section{HLB determination}

Oenocarpus bacaba oil was purchased from the company "Mundo dos Óleos", Brasília, Brazil. All the formulations described in here were prepared using oil from the same batch.
According to the manufacturer, the oil was extracted by cold pressing and presented corresponding quality characteristics. We prepared a series of emulsions containing bacaba oil with increasing HLB (hidrophilic-lipophilic balance). The surfactant mixture fractions of Span 80 (sorbitan monostearate) and Tween 80 (polysorbate 80), and the ratio [w/w (weight/weight)] of the surfactants to obtain the HLB (from six up to 12), were calculated. The samples for each HLB were prepared in triplicate. The aqueous and oily phases were prepared separately, then mixed and kept under manual stirring and heating in an electric water bath at $75^{\circ} \mathrm{C}$ for $15 \mathrm{~min}$. After having been removed from the water bath, the emulsions were kept under manual stirring for fifteen minutes at room temperature. The emulsions were analyzed under a microscope (BEL ${ }^{\circledR}$ Photonics, Italy) at 40x magnification, and the globules were photographed (one picture for each replicate, adding up to three pictures for each HLB value) for determination of their area using the Image $\mathrm{J}^{\oplus}$ software. Mean droplet size, standard deviation and coefficient of variation in function of globule area were calculated (Zanin et al. 2002; Fiori et al. 2017).

\section{System composition}

The microemulsionated systems were developed using bacaba oil, distilled water, sorbitan monostearate (Span $80-$ SP), $\mathrm{HLB}=4.3$; polysorbate 80 (Tween 80 - TW), HLB = 15.0; and butan-1-ol (BT). The reagents used in the study were analytical grade and purchased from Sigma ${ }^{\circledR}$, USA. Butan1 -ol (BT) was used at a ratio of $10 \%$ (fraction =1) in the surfactant mixture. BT is one of the best cosurfactants for the preparation of microemulsions (Kumar et al. 2014; Boonme et al. 2006; Wilk et al. 2009) and its concentration in our formulations is considered residual and non-toxic (USP 2007). The HLB of SP and TW was used to calculate the mix relation of surfactants and cosurfactants, to achieve an HLB corresponding to the oily phase (Ribeiro et al. 2015).

\section{System development}

Thirty six formulations were developed using pre-established quantities of the components, ranging from $10 \%$ to $80 \%$, in order to construct a pseudoternary diagram. The samples were prepared and visually rated after 72 hours at $25^{\circ} \mathrm{C}$ in the following categories: microemulsion (ME), liquid emulsion (LE), and phase separation (PS). Titrations were performed to obtain the boundering points, regions and classification of different systems to form the diagram. Surfactant/oil mixtures were prepared in the mass ratios of $1: 9$ up to 9:1, then distilled water was added in quantities between 0.05 and $0.10 \mathrm{~mL}$, with constant agitation. After homogenization of each mixture, they were visually classified.

Pseudoternary diagrams were obtained from the sample and titration data using the SigmaPlot ${ }^{\circledR}$ version 8.0 software. The superior vertex of the diagrams (Figure 1) represents 


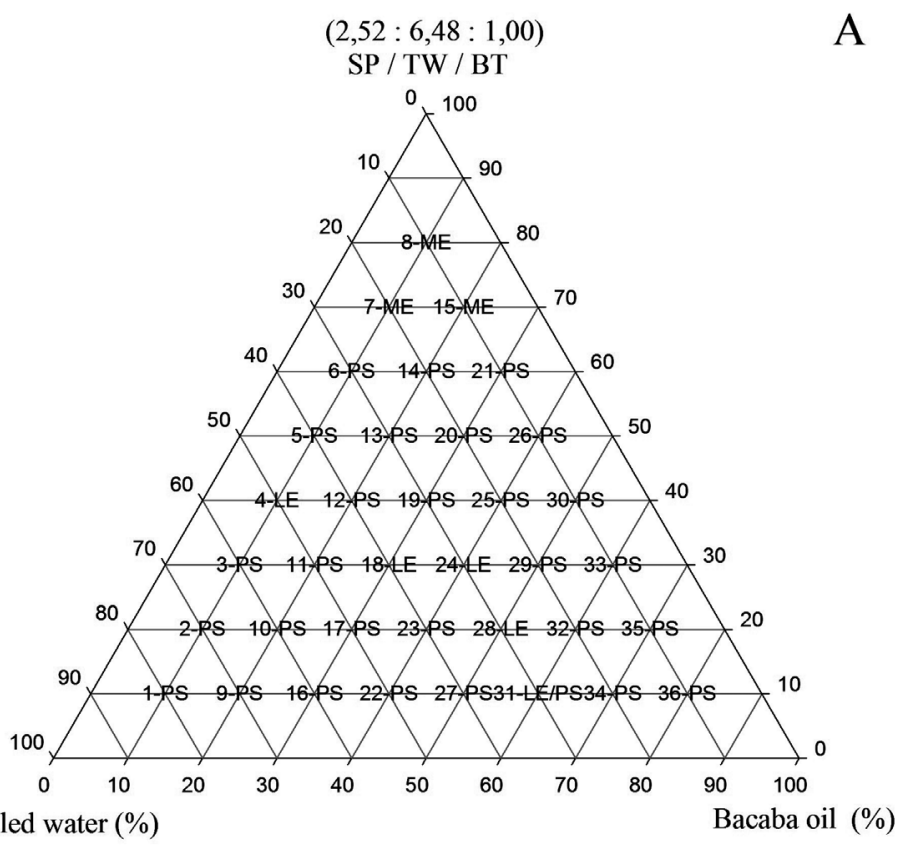

Distilled water (\%)

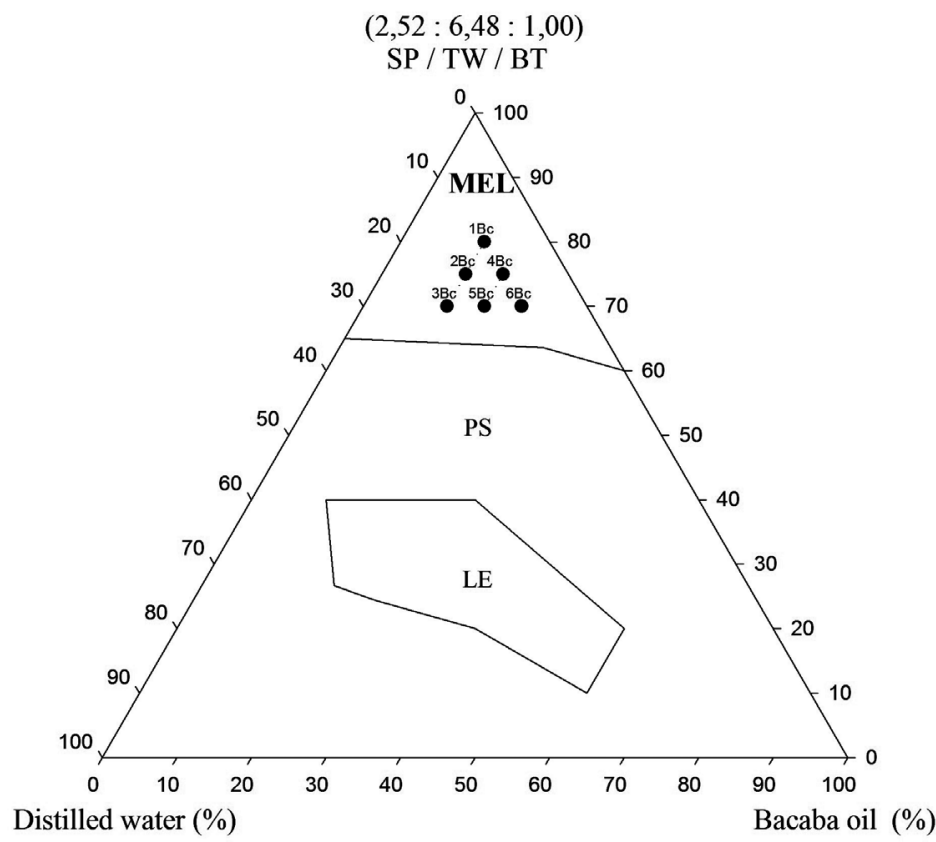

Figure 1. (A) Pseudoternary diagram containing all 36 points for microemulsions of Oenocarpus bacaba oil and their respective classifications. (B) Region diagram showing the microemulsion region (MEL) containing the six selected microemulsions. $L E=$ liquid emulsion; PS = phase separation

$100 \%$ surfactant/cosurfactant mix, the lower right represents $100 \%$ oily phase and the lower left represents $100 \%$ aqueous phase. After acquisition of the pseudoternary phase diagram, the microemulsion region was determined. From this region, microemulsions with different compositions were selected to achieve representative samples of the studied systems.

\section{Stability analysis}

Microemulsion stability was analyzed according to Fiori et al. (2017) and Gustmann et al. (2017). For preliminary stability, the formulations selected from the pseudoternary diagram were submitted to alternate heating/cooling cycles of 24 hours, at $40 \pm 1{ }^{\circ} \mathrm{C}$ and $5 \pm 1{ }^{\circ} \mathrm{C}$, respectively, during 14 
days. Physicochemical characteristics of the formulations were measured before and after the test. The $\mathrm{pH}$ was determined with a $\mathrm{pH}$ meter (DLA-PH, Del Lab, Brazil) calibrated with standard $\mathrm{pH} 7$ and $\mathrm{pH} 4$ buffer solutions. Electrical conductivity was measured using a conductivity meter (MCA150, Tecnopon, Brazil) calibrated with a $0.1 \mathrm{~mol} / \mathrm{L} \mathrm{KCL}$ solution. The refraction index was measured with a digital Abbe refractometer (WYA-2S, Polax, Brazil).

For accelerated stability tests, microemulsions selected from the previous test were submitted to three different conditions, in triplicate: $5 \pm 1{ }^{\circ} \mathrm{C}, 25 \pm 1{ }^{\circ} \mathrm{C}$ and $40 \pm 1{ }^{\circ} \mathrm{C}$. The test lasted 90 days and the physiochemical characteristics were assessed at the beginning of the test and every 30 days.

\section{Rheological characterization}

Rheological parameters were measured for each formulation, before and after the accelerated stability test, according to Fiori et al. (2017) and Gustmann et al. (2017) using a Modular Compact Rheometer (MCR 102, Anton Paar ${ }^{\circledR}$ Germany $\mathrm{GmbH}$, Ostfildern, Germany). The tests were conducted under controlled conditions at $25{ }^{\circ} \mathrm{C}$ and statistically significant differences within samples before and after the test were evaluated using analysis of variance (ANOVA), followed by multiple comparisons by Tukey test. Statistical significance was set at $\mathrm{p}<0.05$.

\section{Dynamic light scattering (DLS)}

Dynamic light scattering analysis were performed using a Zetasizer Nano (Z90, Malvern ${ }^{\circledR}$ Instruments, United Kingdom) with excitation at $632.8 \mathrm{~nm}$, according to Fiori et al. (2017) and Gustmann et al. (2017). Colloidal structures of the formulations were prepared for analysis by the dynamic light scattering technique, to evaluate the hydrodynamic diameter of the dispersed system.

\section{Antioxidant activity}

We determined the potential antioxidant activity using DPPH (2,2-diphenyl-1-pricil-hydrazila) radical scavenging adapted from Elmasta et al. (2006) and Li et al. (2012). Measurements were determined in a spectrophotometer (CIRRUS 80MB, Femto $^{\circledR}$, São Paulo, Brazil). The microemulsions were diluted in methanol, and the oil in a solution of methanol:chloroform $(1: 1)$. The microemulsions selected from the previous tests were tested along four control formulations (pure oil and oil in 10, 15 and $20 \%$ dilution, according to its percentage in the formulations). Absorbance readings were performed at the wavelength of 517 nm using respective white controls. To evaluate the free radical scavenging activity, a calibration curve was build for each formulation, pure oil and oil dilutions. The percentage of $\mathrm{DPPH}$ radical inhibition of each point in the curves was calculated by the following equation: $\%$ inhibition of DPPH $=\left[\left(A_{0}-A_{1}\right) / A_{0}\right.$ $x$ 100], where $A_{0}=$ control absorbance, and $A_{1}=$ absorbance of the sample. The IC50 (half maximal inhibitory concentration) value was calculated using the equation provided by the curve.

\section{RESULTS}

HLB 7 and 12 had similar mean droplet size (Table 1), HLB 7 being a bit smaller, and HLB 12 having lower values of standard deviation and coefficient of variation, which indicates a greater homogeneity of the globules and greater proximity to the ideal HLB. Therefore, two pseudoternary diagrams were constructed, one considering the HLB value of the oil phase as seven and the other as 12 . The HLB 12 diagram formed more microemulsions, showing that HLB 12 was the most adequate, being selected for subsequent analyzes.

The obtained surfactant fractions were 2.52 and 6.48 for SP and TW, respectively, resulting in a surfactant mix relation of 1.0:2.52:6.48 (BT:SP:TW), which was used in the pseudoternary diagram.

The resulting HLB 12 diagram presented 36 points with divergent characteristics (Figure 1a), from which three were visually classified as microemulsions, considering their translucence. After the titrations, it was possible to determine a microemulsion region limit on the diagram (Figure 1b), and, from this region, six different formulations $(1 \mathrm{Bc}, 2 \mathrm{Bc}, 3 \mathrm{Bc}$, $4 \mathrm{Bc}, 5 \mathrm{Bc}$ and $6 \mathrm{Bc}$ ) were selected, which presented different amounts of each phase (at least $10 \%$ of oil and water), aiming to represent the diversity of the microemulsion region. The selected formulations contained at least $70 \%$ of the surfactant mixture, $10 \%$ of the aqueous phase, and an oil phase in a range between $10 \%$ and $20 \%$.

The six formulations were macroscopically stable after centrifugation and were clear and homogeneous, with no sign of phase separation. The $\mathrm{pH}$ values before and after the preliminary stability test ranged between 6.75 and 7.35 . The electric conductivity and refraction index showed a small variation (Table 2 ).

Table 1. Droplet dimension of the series of emulsions with Oenocarpus bacaba oil used to determine the oil's HLB. Diameter values are the mean \pm SD.

\begin{tabular}{llc}
\hline$H L B$ & Diameter $\left(\mathrm{mm}^{2}\right)$ & Coefficient of variation \\
\hline 6.0 & $0.0325 \pm 0.1326$ & 4.0752 \\
6.5 & $0.0186 \pm 0.0873$ & 4.7041 \\
7.0 & $0.0065 \pm 0.0065$ & 0.9988 \\
7.5 & $0.0361 \pm 0.1520$ & 4.2056 \\
8.0 & $0.0588 \pm 0.2156$ & 3.6681 \\
8.5 & $0.0076 \pm 0.0084$ & 1.1062 \\
9.0 & $0.0355 \pm 0.1535$ & 4.3307 \\
9.5 & $0.0354 \pm 0.1604$ & 4.5363 \\
10.0 & $0.0507 \pm 0.1913$ & 3.7722 \\
10.5 & $0.0355 \pm 0.1574$ & 4.4327 \\
11.0 & $0.0227 \pm 0.1151$ & 5.0792 \\
11.5 & $0.0066 \pm 0.0091$ & 1.3707 \\
12.0 & $0.0066 \pm 0.0056$ & 0.8552 \\
\hline
\end{tabular}


Table 2. Physicochemical parameters of the six selected formulations of Oenocarpus bacaba oil microemulsions after preliminary stability tests ( 14 days). no $=$ no phase separation. Values are the mean \pm SD of three replicates.

\begin{tabular}{|c|c|c|c|c|c|c|}
\hline Formulation & $1 \mathrm{BC}$ & $2 \mathrm{BC}$ & $3 B C$ & $4 \mathrm{BC}$ & $5 B C$ & $6 B C$ \\
\hline Centrifugation & no & no & no & no & no & no \\
\hline pH & $7.35 \pm 0.11$ & $7.20 \pm 0.11$ & $6.93 \pm 0.03$ & $7.14 \pm 0.06$ & $7.07 \pm 0.05$ & $7.17 \pm 0.08$ \\
\hline Conductivity $\left(\mu \mathrm{Scm}^{-1}\right)$ & $9.83 \pm 0.63$ & $17.66 \pm 2.63$ & $35.46 \pm 0.82$ & $9.34 \pm 0.09$ & $20.66 \pm 0.58$ & $9.22 \pm 0.36$ \\
\hline Refraction index & $1.4550 \pm 0.0006$ & $1.4490 \pm 0.0016$ & $1.4429 \pm 0.0002$ & $1.4552 \pm 0.0004$ & $1.4492 \pm 0.0002$ & $1.4554 \pm 0.0002$ \\
\hline \multicolumn{7}{|c|}{ After heating-cooling cycles } \\
\hline $\mathrm{pH}$ & $7.16 \pm 0.23$ & $6.90 \pm 0.09$ & $6.75 \pm 0.03$ & $7.00 \pm 0.02$ & $6.91 \pm 0.03$ & $7.01 \pm 0.06$ \\
\hline Conductivity $\left(\mathrm{mScm}^{-1}\right)$ & $6.69 \pm 3.94$ & $16.13 \pm 1.85$ & $32.46 \pm 1.55$ & $8.22 \pm 0.22$ & $17.53 \pm 0.44$ & $8.57 \pm 0.67$ \\
\hline Refraction index & $1.4555 \pm 0.0062$ & $1.4497 \pm 0.0021$ & $1.4441 \pm 0.0003$ & $1.4559 \pm 0.0003$ & $1.4499 \pm 0.0013$ & $1.4558 \pm 0.0005$ \\
\hline
\end{tabular}

In the accelerated stability test, the $\mathrm{pH}$ of the microemulsions varied slightly, settling around 7 (Table 3). Mean conductivity in all formulations remained above $1.3 \mu \mathrm{Scm}^{-1}$ after the 90 -day test period (Table 3 ), characterizing them as $\mathrm{O} / \mathrm{W}$ (oil in water) microemulsions, and indicating stability and non inversion of the system phases. The refraction index of the formulations also remained constant over time (Table 3).

The formulations displayed a flow curve with linear ascending and descending behavior, and viscosity values that did not change with the increase of the shear rate, characterizing them as Newtonian fluids. Formulations 2Bc, $3 \mathrm{Bc}, 4 \mathrm{Bc}$ and $5 \mathrm{Bc}$ maintained statistically similar equivalent stability profiles (ANOVA 90 days: $\mathrm{F}=0.952 ; \mathrm{p}=0.533$ ) (Figure 2), while $1 \mathrm{Bc}$ and $6 \mathrm{Bc}$ differed significantly $(\mathrm{p}<0.01)$ and were therefore not included in Figure 2. Formulations $2 \mathrm{Bc}, 3 \mathrm{Bc}$ and $5 \mathrm{Bc}$ had statistically similar viscosity values at the beginning and end of the stability analysis (Figure 3), while $1 \mathrm{Bc}, 4 \mathrm{Bc}$ and $6 \mathrm{Bc}$ differed significantly $(\mathrm{p}<0.01)$ and were therefore not included in Figure 3 (ANOVA 90 days: $\mathrm{F}=$ 29.724; $p<0.0001-2 B c: p>0.05,3 B c: p>0.05$ and 5Bc: $p>$ $0.05)$. Therefore we concluded that formulations $2 \mathrm{Bc}, 3 \mathrm{Bc}$ and $5 \mathrm{Bc}$ were the ones with greater reological stability over time.

Mean droplet size ranged between 130 and $250 \mathrm{~nm}$ (Figure 4). The PDI values ranged between 0.18 and 0.33 , indicating homogeneity of the globules in the formulations. The hydrodynamic diameter of all six final formulations was dependent on the proportion of the constituents, since there was a statistical difference among them $(\mathrm{p}<0.001)$.

The oil with no dilution had the lowest IC50, and, therefore, the best antioxidant activity. All formulations had IC50 values indicative of better antioxidant activity than their respective oil dilutions (Figure 5).
Table 3. Physicochemical parameters of the six selected formulations of Oenocarpus bacaba oil microemulsions during the accelerated stability test (determined at 0, 30,60 and 90 days). Values are the mean \pm SD of three replicates

\begin{tabular}{|c|c|c|c|c|}
\hline \multirow{2}{*}{ Formulation } & 0 & 30 & 60 & 90 \\
\hline & \multicolumn{4}{|c|}{$\mathrm{pH}$} \\
\hline $1 \mathrm{BC}$ & $7.47 \pm 0.10$ & $7.19 \pm 0.25$ & $7.33 \pm 0.27$ & $7.07 \pm 0.38$ \\
\hline $2 \mathrm{BC}$ & $7.35 \pm 0.11$ & $7.04 \pm 0.33$ & $7.18 \pm 0.28$ & $6.94 \pm 0.35$ \\
\hline $3 B C$ & $7.19 \pm 0.06$ & $6.88 \pm 0.32$ & $7.18 \pm 0.35$ & $6.80 \pm 0.53$ \\
\hline $4 \mathrm{BC}$ & $7.41 \pm 0.10$ & $7.14 \pm 0.26$ & $7.35 \pm 0.28$ & $7.16 \pm 0.37$ \\
\hline $5 B C$ & $7.32 \pm 0.18$ & $7.17 \pm 0.15$ & $7.28 \pm 0.23$ & $7.05 \pm 0.24$ \\
\hline $6 \mathrm{BC}$ & $7.47 \pm 0.19$ & $7.31 \pm 0.16$ & $7.39 \pm 0.13$ & $7.23 \pm 0.30$ \\
\hline
\end{tabular}

Conductivity $\left(\mu \mathrm{Scm}^{-1}\right)$

\begin{tabular}{lllll}
\hline $1 B C$ & $7.89 \pm 0.68$ & $9.05 \pm 1.07$ & $8.34 \pm 0.95$ & $9.78 \pm 4.28$ \\
\hline $2 B C$ & $15.63 \pm 1.80$ & $16.90 \pm 2.21$ & $18.14 \pm 5.73$ & $29.74 \pm 25.59$ \\
$3 B C$ & $28.37 \pm 3.13$ & $30.11 \pm 4.72$ & $25.28 \pm 9.40$ & $30.03 \pm 12.03$ \\
\hline $4 B C$ & $7.83 \pm 0.96$ & $9.01 \pm 1.50$ & $6.84 \pm 1.74$ & $8.14 \pm 1.34$ \\
$5 B C$ & $15.20 \pm 0.25$ & $15.52 \pm 3.56$ & $12.45 \pm 4.98$ & $14.33 \pm 6.22$ \\
\hline $6 B C$ & $7.15 \pm 0.10$ & $7.41 \pm 2.21$ & $5.61 \pm 3.05$ & $6.93 \pm 3.13$ \\
\hline
\end{tabular}

Refraction Index

\begin{tabular}{llllll}
\hline $1 B C$ & $1.4553 \pm 0.0007$ & $1.4544 \pm 0.0011$ & $1.4565 \pm 0.0014$ & $1.4577 \pm 0.0054$ \\
\hline $2 B C$ & & $1.4495 \pm 0.0012$ & $1.4488 \pm 0.0009$ & $1.4585 \pm 0.0093$ & $1.4559 \pm 0.0108$ \\
\hline$B B C$ & & $1.4439 \pm 0.0020$ & $1.4438 \pm 0.0017$ & $1.4479 \pm 0.0087$ & $1.4484 \pm 0.0090$ \\
$4 B C$ & & $1.4545 \pm 0.0013$ & $1.4545 \pm 0.0013$ & $1.4574 \pm 0.0019$ & $1.4584 \pm 0.0050$ \\
$5 B C$ & & $1.4544 \pm 0.0137$ & $1.4508 \pm 0.0028$ & $1.4539 \pm 0.0042$ & $1.4531 \pm 0.0047$ \\
$6 B C$ & & $1.4552 \pm 0.0005$ & $1.4567 \pm 0.0030$ & $1.4601 \pm 0.0052$ & $1.4593 \pm 0.0040$
\end{tabular}




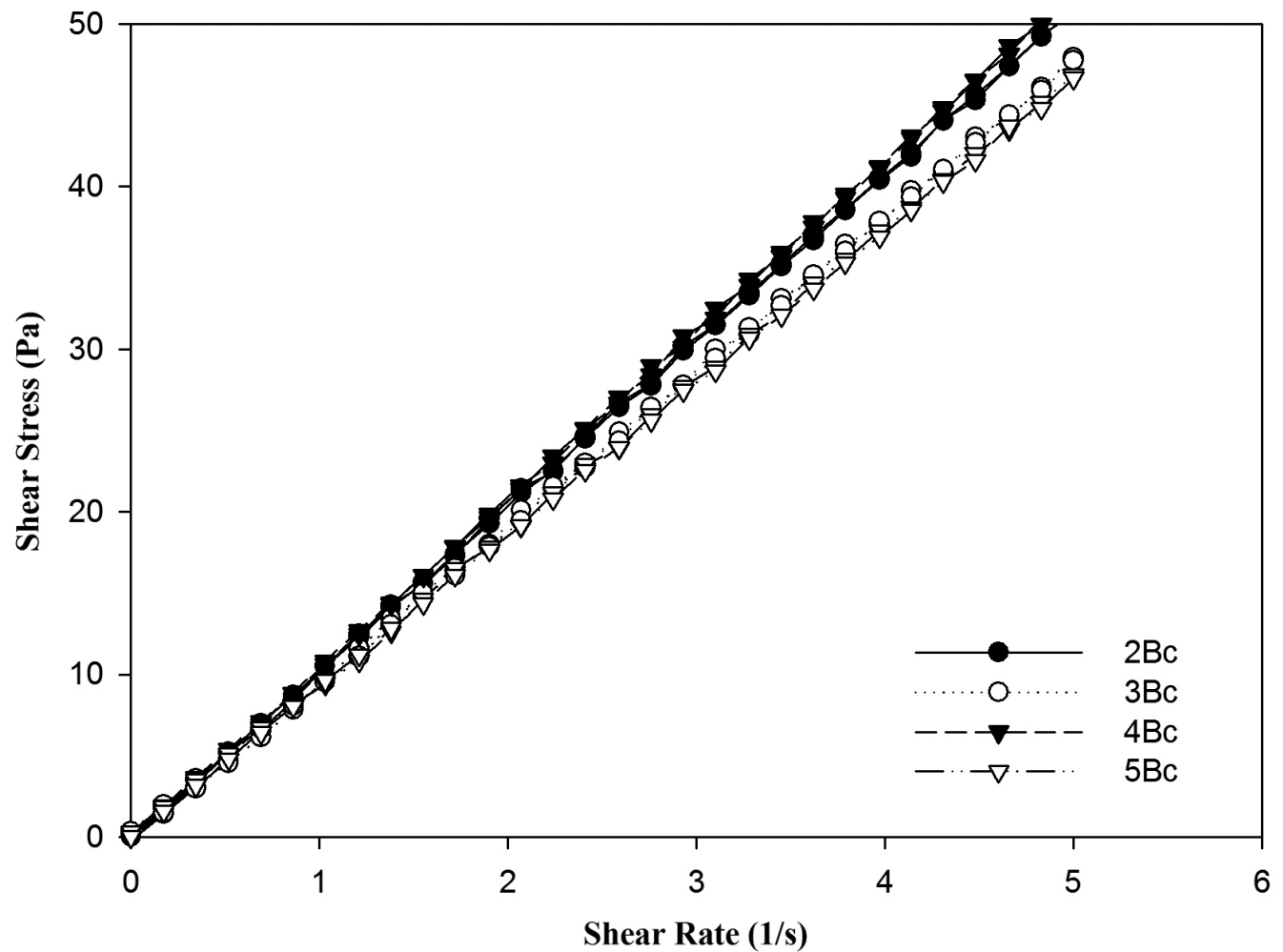

Figure 2. Flow curve of the selected microemulsions of Oenocarpus bacaba oil before and after the accelerated stability test, considering only the microemulsions that did not differ significantly before and after the test.

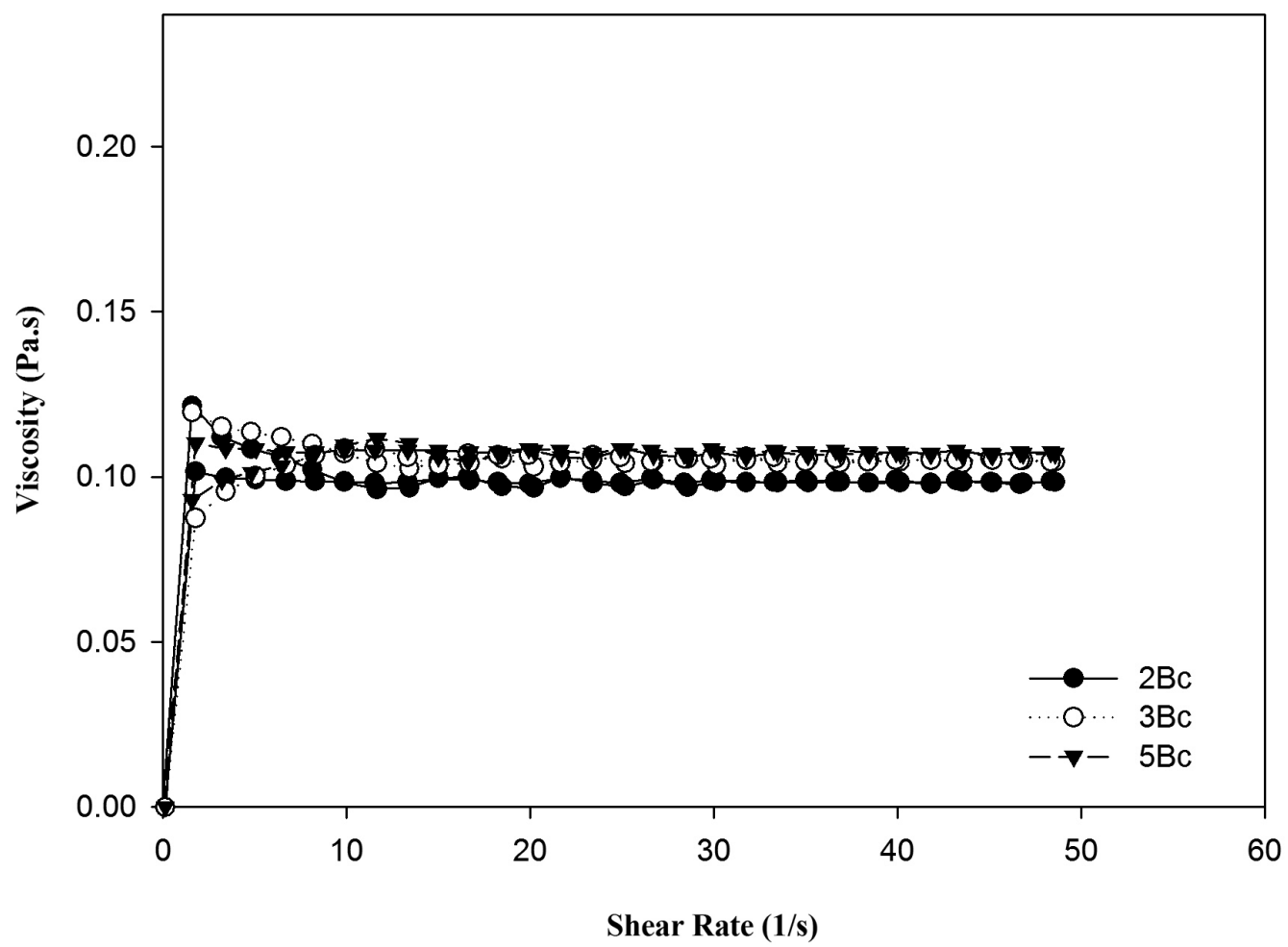

Figure 3. Viscosity curve of the microemulsions of Oenocarpus bacaba oil before and after the accelerated stability test, considering only the microemulsions that did not differ significantly before and after the test. 


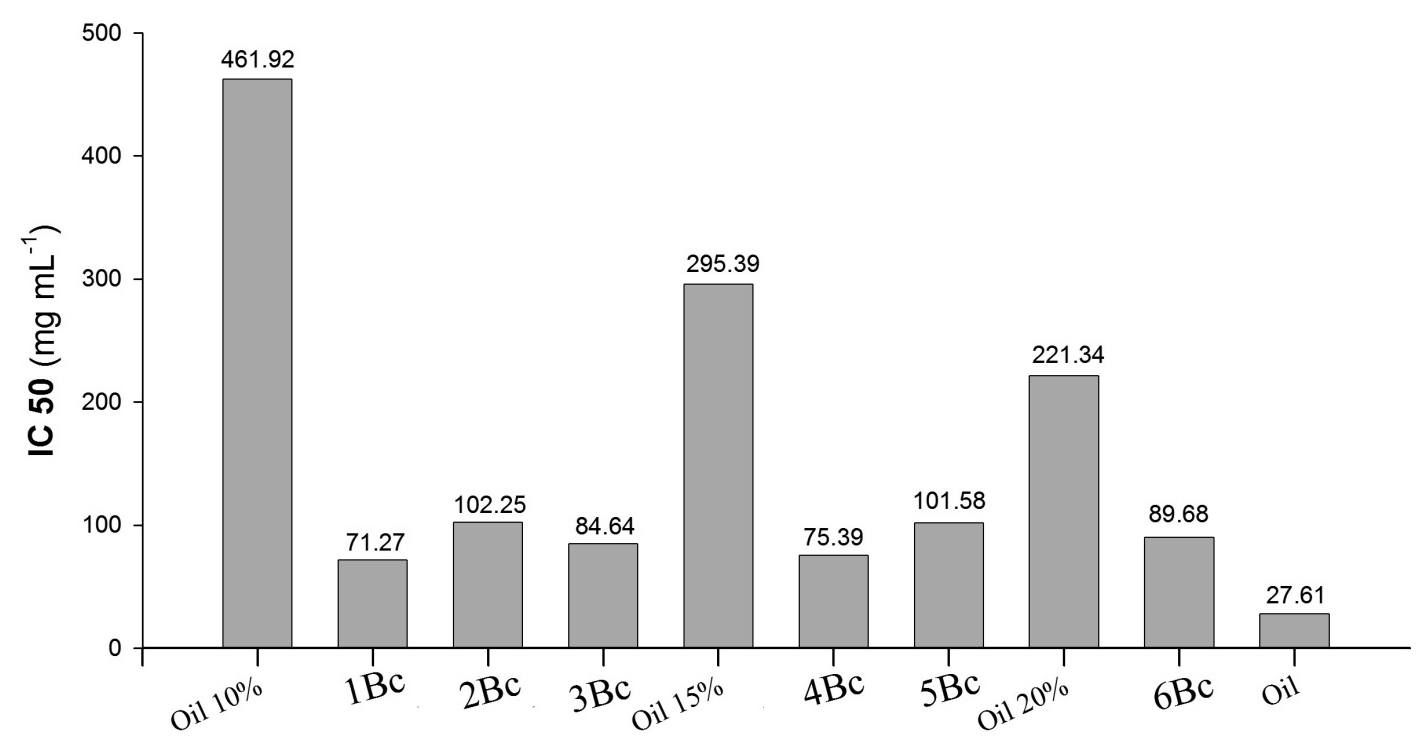

Figure 4. Potential antioxidant activity (IC50) of the microemulsions of Oenocarpus bacaba oil approved in the stability tests, compared with the values for pure oil and its dilutions (10, 15 and $20 \%)$.

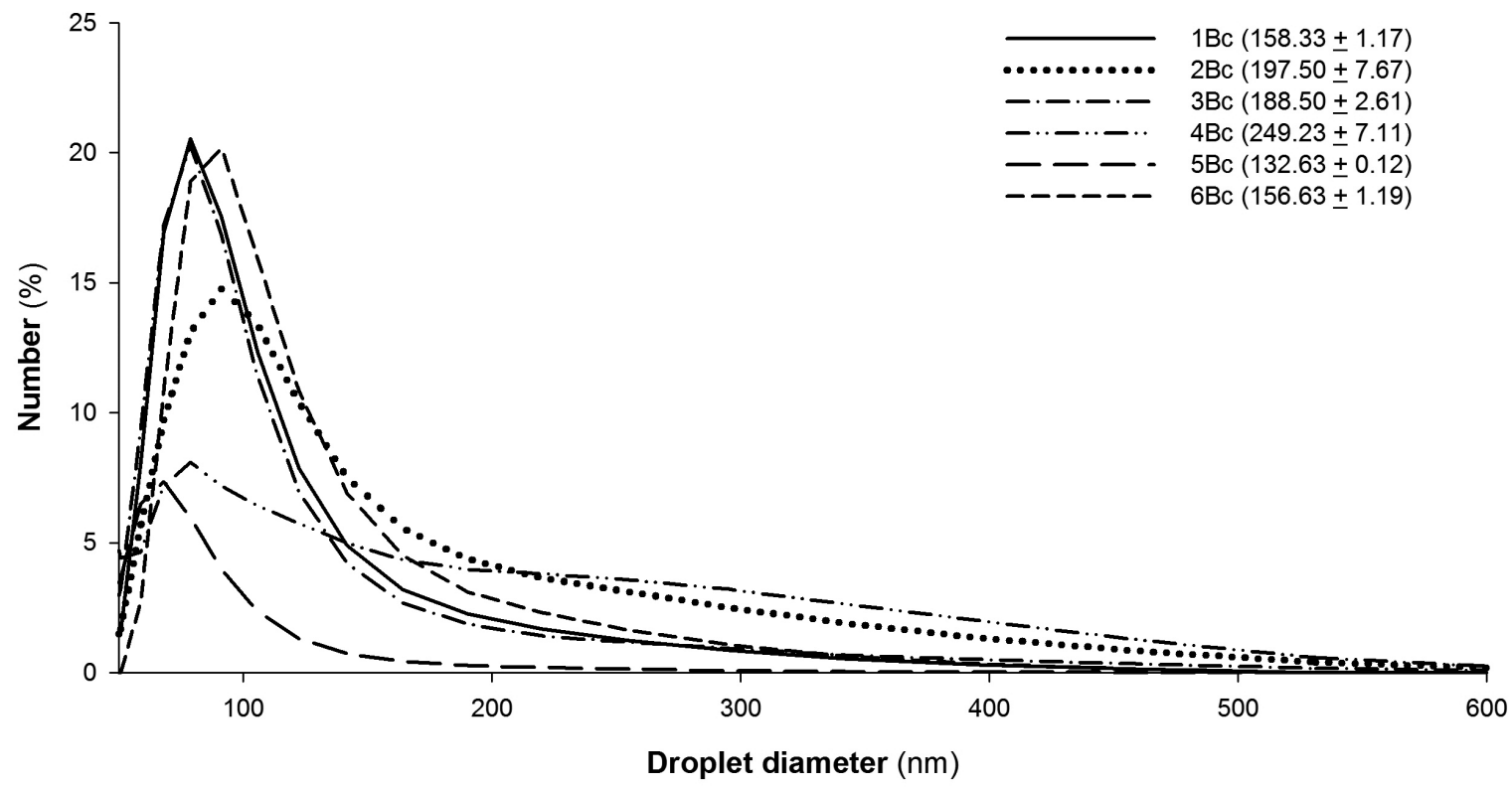

Figure 5. Droplet hydrodynamic diameter of the microemulsions of Oenocarpus bacaba oil approved in the stability tests. In the graph legend, values in brackets after the microemulsion code are the mean followed by the standard deviation.

\section{DISCUSSION}

The HLB obtained for bacaba oil in our sample was the same as that for olive oil (Frange and Garcia 2009), which may be due to a similarity in fatty acid composition of both oils, whith oleic acid in largest proportion (Santos et al. 2017; Wani et al. 2018).

The high surfactant concentration in the selected formulations coincides with that employed in other studies of microemulsion prospection (Ribeiro et al. 2015; Boonme et al. 2006; Prajapati et al. 2012; Fiori et al. 2017). The high proportion of surfactant results from the need to reduce the surface tension between the oily and aqueous phase, to enable smaller droplet sizes and provide stability to the formulation, the basic characteristics of viable microemulsions (Fanun 2012; Pessoa et al. 2015).

The formulations were characterized as $\mathrm{O} / \mathrm{W}$ microemulsions, because $1.3 \mu \mathrm{Scm}^{-1}$ is the electrical 
conductivity of water, and the values above represent water as the outside phase in the microemulsion system (Pessoa $e t$ al. 2015; Lanes et al. 2016).

The range of $\mathrm{pH}$ values in our formulations are indicative of stability, since variability in this parameter can indicate the presence of impurities, hydrolysis and/or decomposition of the system constituents, which cause instability (Pianovski et al. 2008). Moreover, $\mathrm{pH} 7$ is considered the most adequate to different routes of administration (Franco and Bochi 2013). Likewise, the constance of our refraction indices over time are indicative of stable, translucent and homogeneous microemulsion systems, since unstable and inhomogeneous mixtures are usually turbid (Ferreira et al. 2006).

The Newtonian behavior of our formulations corroborates other studies on microemulsions containing oil extracted from natural products (Fiori et al. 2017; Torres et al. 2018). Microemulsions with a Newtonian profile tend to show stability over a long period of time (Ribeiro et al. 2015; Pessoa et al. 2015; Lanes et al., 2016), however, the composition of the system may influence this characteristic in the formulations, since other studies with microemulsions containing different surfactants resulted in a non-Newtonian profile (Jiao and Burgees 2003).

The droplet size in our formulations (in the order of nanometres) was consistent with that obtained in other studies (Fiori et al. 2017; Torres et al. 2018).

The potential antioxidant activity of our pure oil was similar to that of açai (Euterpe oleraceae) oil (Rufino et al. 2011). The higher activity of the formulations relative to the oil dilutions was probably due to the incorporation of the oil into the formulation, which may influence its behavior (Hamed et al. 2012; Chaiyana et al. 2014). Although the antioxidant activity of the formulations was higher then that of the diluted oil, it was not as high as that of microemulsions with olive oil (Chaiyana et al. 2016). The choice of the carrier can either increase or decrease the potential antioxidant activity of the microemulsion, thus the choice of surfactant is important, since these substances may or may not present antioxidant activity when isolated (Kim et al. 2009; PérezRosés et al. 2014).

\section{CONCLUSIONS}

Bacaba oil microemulsions developed with a greater amount of water $(2 \mathrm{Bc}, 3 \mathrm{Bc}$ and $5 \mathrm{Bc})$ were stable and increased the antioxidant potential of bacaba oil when compared with their respective oil dilutions. The water amount may facilitate the incorporation of hidrofilic substances to the microemulsion. The three selected bacaba oil microemulsions have potential as carriers in the pharmaceutical, cosmetic, food and/or agriculture industry.

\section{ACKNOWLEDGMENTS}

The financial support from the Brazilian agencies CNPq (Conselho Nacional de Desenvolvimento Científico e Tecnológico) and FAPEMAT (Fundaçấo de Amparo à Pesquisa do Estado de Mato Grosso; process nr. 224179/2015) is gratefully acknowledged.

\section{REFERENCES}

Albagli, S. 2001. Amazônia: fronteira geopolítica da biodiversidade. Parcerias Estratégicas, 12: 5-19.

Balick, M.J. 1986. Systematics and economic botany of the Oenocarpus-jessenia (Palmae) complex. Advances in Economic Botany, 3: 1-140.

Bonifácio, B.V.; da Silva, P.B.; Ramos, M.A. dos S.; Negri, K.M.S.; Bauab, T.M.; Chorilli, M. 2014. Nanotechnology-based drug delivery systems and herbal medicines: a review. International Journal of Nanomedicine, 9: 1-15.

Boonme, P.; Krauel, K.; Graf, A.; Rades, T.; Junyaprasert, V.B. 2006. Characterization of microemulsion structures in the pseudoternary phase diagram of isopropyl palmitate/water/Brij 97:1-butanol. AAPS PharmSciTech, An Official Journal of the American Association of Pharmaceutical Scientists, 7: e45.

Callender, S.P.; Mathews, J.A.; Kobernyk, K.; Wettig, S.D. 2017. Microemulsion utility in pharmaceuticals: Implications for multi-drug delivery. International Journal of Pharmaceutics, 526: 425-442.

Chaiyana, W.; Leelapornpisid, P.; Phongpradist, R.; Kiasttisin, K. 2016. Enhancement of antioxidant and skin moisturizing effects of olive oil by incorporation into microemulsions. Nanomaterials and Nanotechnology, 6: 1-7.

Chaiyana, W.; Phongpradist, R.; Leelapornpisid, P. 2014. Characterization of hydrodistillated pomelo peel oil and the enhancement of biological activities using microemulsion formulations. International Journal of Pharmacy and Pharmentical Sciences, 6: 596-602.

Costa, R.; Santos, L. 2017. Delivery systems for cosmetics - From manufacturing to the skin of natural antioxidants. Powder Technology, 322: 402-416.

Cotrim, A.C. de M.; Honorio-França, A.C.; França, E.L. 2016. Rheology analysis can be added in thermal stability test for design microemulsion materials. Biointerface Research in Applied Chemistry, 6: 1128-1135.

Dasgupta, N.; Ranjan, S.; Mundekkad, D.; Ramalingam, C.; Shanker, R.; Kumar, A. 2015. Nanotechnology in agro-food: From field to plate. Food Research International. 69: 381-400.

Elmasta, M.; Gulçin, I.; Isildak, O.; Küfrevio, Ö.; Ibaoglu, K.; AboulEnein, H.Y. 2006. Radical scavenging activity and antioxidant capacity of bay leaf extracts. Journal of the Irananian Chemical Society, 3: 258-266.

Fanun, M. 2012. Microemulsion as delivery systems. Current Opinion in Colloid and Interface Science. 17: 306-313.

Ferreira, E. de S.; Silveira, C. da S.; Lucien, V.G.; Amaral, A.S. 2006. Caracterizaçáo físico-química da amêndoa, torta e composição dos ácidos graxos majoritários do óleo bruto da castanha-do- 
Brasil (Bertholletia excelsa H.B.K). Alimentos e Nutrição, 17: 203-208.

Finco, F.D.B.; Kammerer, D.R.; Carle, R.; Tseng, W.; Böser, S.; Graeve, L. 2012. Antioxidant activity and characterization of phenolic compounds from bacaba (Oenocarpus bacaba Mart.) fruit by HPLC-DAD-MS. Journal of Agricultural and Food Chemistry, 60: 7665-7673.

Fiori, K.P.; Torres, M.P.R., Schons, J.I.; Ribeiro, E.B.; Nogueira, R.M.; Vasconcelos, L.G.; Andrighetti, C.R.; Jacinto, M.J.; Valladão, D.M.S. 2017. Microemulsion of Brazil nut oil as a natural product to improve superoxide release in human phagocytes. Quimica Nova, 40: 1051-1057.

Franco, L.T.; Bochi, L.D.C.S. 2013. Produção e caracterização de diferentes formulaçôes tópicas semissólidas contendo meloxicam na forma nanoestruturada. Vivências: Revista Eletrônica de Extensão da URI, 9: 209-231.

Frange, R.C.C.; Garcia, M.T.J. 2009. Desenvolvimento de emulsões óleo de oliva/água: avaliação da estabilidade física. Revista de Ciências Farmacêuticas Básica e Aplicada, 30: 263-271.

Funari, C.S.; Ferro, V.O. 2005. Uso ético da biodiversidade brasileira: necessidade e oportunidade. Revista Brasileira de Farmacognosia, 15: 178-182.

Gustmann, P.C.; Cotrim, A.C.M.; Pires, E.M.; Andrighetti, C.R.; Valladão, D.M.S.; Ribeiro, E.B. 2017. Development of Brazil nut oil microemulsion as vehicle for levamisole. Journal of Applied Pharmaceutical Science, 7: 92-98.

Hamed, S.F.; Sadek, Z.; Edris, A. 2012. Antioxidant and antimicrobial activities of clove bud essential oil and eugenol nanoparticles in alcohol-free microemulsion. Journal of Oleo Science, 61: 641-648.

Jiao, J.; Burgess, D.J. 2003. Rheology and stability of water-in-oilin-water multiple emulsions containing Span 83 and Tween 80. AAPS PharmSciTech, An Official Journal of the American Association of Pharmaceutical Scientists, 5: e7.

Katz, L.M.; Dewan, K.; Bronaugh, R.L. 2017. Nanotechnology in cosmetics. Food and Chemical Toxicology, 85: 127-137.

Kim, S.; Kiong, W.; Shen, S.; Dong, Y.; Tan, R.B.H. 2009. Phase behavior, microstructure transition, and antiradical activity of sucrose laurate / propylene glycol / the essential oil of Melaleuca alternifolia / water microemulsions. Colloids Surfaces A: Physicochemical and Engineering Aspects, 348: 289-297.

Kumar, A.; Kushwaha, V.; Sharma, P.K. 2014. Pharmaceutical microemulsion: Formulation, characterization and drug deliveries across skin. International Journal of Drug Development and Research, 6: 1-21.

Lanes, P.K.D.; Ribeiro, E.B.; Chaud, N.G.A.; Pessoa, R.S.; França, E.L.; Honorio-frança, A.C. 2016. Effects of microemulsion incorporated with Orbignya martiana Rodr on the functional activity of blood phagocytes. Wulfenia Journal, 1: 214-236.

Lawrence, M.J.; Rees, G.D. 2012. Microemulsion-based media as novel drug delivery systems. Advanced Drug Delivery Reviews, 45: 89-121.

Li, W.J.; Cheng, X.L.; Liu, J.; Lin, R.C.; Wang, G.L.; Du, S.S.; Liu, Z.L. 2012. Phenolic compounds and antioxidant activities of Liriope muscari. Molecules, 17: 1797-1808.
Oliveira, A.G.; Scarpa, M.V.; Correa, M.A.; Cera, L.F.R.; Formariz, T.P. 2004. Microemulsóes: estruturas e aplicaçoes como sistema de liberação de fármacos. Química Nova, 27: 131-138.

Pereira, S.A.; Alves, H.P.; Sousa, C.M.; Costa, G.L.S.; 2013. Prospecção sobre o conhecimento de espécies amazônicas inajá (Maximiliana maripa Aublt.) e bacaba (Oenocarpus bacaba Mart.). Innovation, Technology and Management Journal, 3: 110-122.

Pérez-Rosés, R.; Risco, E.; Vila, R.; Peñalver, P.; Cañigueral, S. 2014. Antioxidant activity of Tween- 20 and Tween- 80 evaluated through different in-vitro tests. Journal of Pharmacy and Pharmacology, 67: 666-672.

Pessoa, R.S.; França, E.L.; Ribeiro, E.B.; Abud, N.G.; HonorioFrança, A.C. 2015. Microemulsion of babassu oil as a natural product to improve human immune system function. Drug Design Development and Therapy, 9: 21-31.

Pianovski, A.R.; Lima, C.G.; Silva, K.K.; Franco, V.; Carvalho, M.; Musis, C.R. De; Regina, S.; Machado, P. 2008. Desenvolvimento e avaliação da estabilidade de emulsóes múltiplas $\mathrm{O} / \mathrm{A} / \mathrm{O}$ com óleo de pequi (Caryocar brasilienses). Revista Brasileira de Farmácia, 89: 155-159.

Pinto, R.H.H.; Sena, C.; Santos, O.V.; da Costa, W.A.; Rodrigues, A.M.C.; Carvalho Junior, R.N. 2018. Extraction of bacaba (Oenocarpus bacaba) oil with supercritical $\mathrm{CO}_{2}$ : Global yield isotherms, fatty acid composition, functional quality, oxidative stability, spectroscopic profile and antioxidant activity. Grasas y Aceites, 69: e246.

Prajapati, H.N.; Dalrymple, D.M.; Serajuddin, A.T.M. 2012. A comparative evaluation of mono-, di- and triglyceride of medium chain fatty acids by lipid / surfactant / water phase diagram, solubility determination and dispersion testing for application in pharmaceutical dosage form development. Pharmaceutical Research, 29: 285-305.

Queiroz, M.S.M.; Bianco, R. 2009. Morfologia e desenvolvimento germinativo de Oenocarpus bacaba Mart. (Arecaceae) da Amazônia Ocidental. Revista Árvore, 33: 1037-1042.

Ribeiro, E.B.; Kelly, P.; Lanes, D.; Galdeano, N.; Chaud, A.; Pessoa, R. S.; Honorio-França, A.C.; França, E.L. 2015. Microemulsions with levamisole delivery systems as novel immunomodulating agents with potential for amebiasis therapies. Science of Advanced Matererials, 7: 15-27.

Roy, B.C.; Sasaki, M.; Goto, M. 2006. Effect of temperature and pressure on the extraction yield of oil from sunflower seed with supercritical carbon dioxide. Journal of Applied Sciences, 6: 71-75.

Rufino, M.S.M.; Pérez-Jimenez, J.; Arranz, S.; Alves, R.E.; Brito, E.S.; Oliveira, M.S.P.; Saura-Calixto, F. 2011. Açaí (Euterpe oleraceae) 'BRS Pará: A tropical fruit source of antioxidant dietary fiber and high antioxidant capacity oil. Food Research International, 44: 2100-2106.

Santos, M.F.G.; Alves, R.E.; Brito, E.S.; Silva, S.M.; Silveira, M.R.S. 2017. Quality characteristics of fruits and oils of palms native to the brazilian amazon. Revista Brasileira de Fruticultura, 39: e305.

Cymerys, M. 2005. Bacaba (Oenocarpus bacaba Mart.) In: Shanley, P.; Medina, G. (Ed.). Frutiferas e plantas úteis na vida amazônica. CIFOR, Imazon, Belém, p.177-180. 
Torres, M.P.R.; Raiser, A.L.; Marcílio, M.R.; Ribeiro, E.B.; Andrighetti, C.R.; Valladão, D.M.S. 2018. Development, stability and antioxidant activity of microemulsion containig pequi (Caryocar brasiliense Camb.) oil. Revista Virtual de Quimica, 10: 346-361.

United States Pharmacopeial Convention. 2007. United States Pharmacopeia. 30 th ed./NF25. USPC, Rockville, 2007, 3000p.

Wani, T.A.; Masoodi, F.A.; Gani, A.; Baba, W.N.; Rahmanian, N.; Akhter, R.; Wani, I.A.; Ahmad, M. 2018. Olive oil and its principal bioactive compound: Hydroxytyrosol - A review of the recent literature. Trends in Food, Science \& Technology, 77: 77-90.
Wilk, K.A; Zielińska, K.; Hamerska-Dudra, A.; Jezierski, A. 2009. Biocompatible microemulsions of dicephalic aldonamide-type surfactants: formulation, structure and temperature influence. Journal of Colloid and Interface Science, 334: 87-95.

Zanin, S.M.; Miguel, M.D.; Chimelli, M.C.; Oliveira, A.B.; 2002. Determinação do Equilíbrio hidrófilo-lipófilo (EHL) de óleos de origem vegetal. Visão Acadêmica, 3: 13-18.

RECEIVED: $30 / 07 / 2018$

ACCEPTED: 05/05/2019

ASSOCIATE EDITOR: Valdir Veiga Junior 